\title{
Correction: Extra-mitochondrial citrate synthase initiates calcium oscillation and suppresses age-dependent sperm dysfunction
}

\author{
Woojin Kang • Yuichirou Harada - Kenji Yamatoya (D) Natsuko Kawano - Seiya Kanai • Yoshitaka Miyamoto • \\ Akihiro Nakamura - Mami Miyado • Yoshiki Hayashi (D) Y Yoko Kuroki • Hidekazu Saito • Yasuhiro Iwao • \\ Akihiro Umezawa $\cdot$ Kenji Miyado (D)
}

Published online: 6 January 2020

(c) The Author(s) 2020. This article is published with open access

\section{Correction to: Laboratory Investigation}

https://doi.org/10.1038/s41374-019-0353-3

The article Extra-mitochondrial citrate synthase initiates calcium oscillation and suppresses age-dependent sperm dysfunction, written by Woojin Kang, Yuichirou Harada, Kenji Yamatoya, Natsuko Kawano, Seiya Kanai, Yoshitaka Miyamoto, Akihiro Nakamura, Mami Miyado, Yoshiki Hayashi, Yoko Kuroki, Hidekazu Saito, Yasuhiro Iwao, Akihiro Umezawa and Kenji Miyado, was originally published electronically on the publisher's internet portal on 19th December 2019 without open access. With the authors' decision to opt for Open Choice the copyright of the article changed on 9th January to () The Author(s) 2019 and the article is forthwith distributed under a Creative Commons Attribution 4.0 International License (https://crea tivecommons.org/licenses/by/4.0/), which permits use, sharing, adaptation, distribution and reproduction in any medium or format, as long as you give appropriate credit to the original author(s) and the source, provide a link to the Creative Commons licence, and indicate if changes were made.

The original version of this article was revised due to a retrospective Open Access order.

Open Access This article is licensed under a Creative Commons Attribution 4.0 International License, which permits use, sharing, adaptation, distribution and reproduction in any medium or format, as long as you give appropriate credit to the original author(s) and the source, provide a link to the Creative Commons license, and indicate if changes were made. The images or other third party material in this article are included in the article's Creative Commons license, unless indicated otherwise in a credit line to the material. If material is not included in the article's Creative Commons license and your intended use is not permitted by statutory regulation or exceeds the permitted use, you will need to obtain permission directly from the copyright holder. To view a copy of this license, visit http://creativecommons. org/licenses/by/4.0/. 